УДК 347.426

DOI https://doi.org/10.32849/2663-5313/2020.2.11

\title{
Ольга Таран,
}

канд. юрид. наук,

дочент кафедри адміністративних та иивільно-правових дисщиплін

Прикарпатського факультету

Національної академії внутрішніх справ

\section{ВІДШКОДУВАННЯ ШКОДИ, ЗАВДАНОЇ СКАСУВАННЯМ АБО ЗАТРИМКОЮ АВІАРЕЙСУ, ЗА ДОГОВОРОМ НА ТУРИСТИЧНЕ ОБСЛУГОВУВАННЯ}

Стаття присвячена дослідженню проблематики стягнення компенсацї за скасування або затримку рейсу у разі, якщо авіаперевезення є складовою частиною туристичного продукту за договором на туристичне обслуговування. На основі аналізу норм українського законодавства, права Європейського Союзу та судової практики у справах про відшкодування шкоди, завданої неналежним наданням туристичних послуг, проведено відмежування понять «скасування рейсу» та «затримка рейсу». Автором обгрунтовується, що використання в украйнському законодавстві поняття «розумні строки» у характеристиці затримки та скасування рейсу зумовлює нечітке визначення критеріїв їх розмежування під час вирішення питання про призначення компенсачії. На основі характеристики рішень Свропейського суду пропонується уточнення пункту 6 розділу I Авіачійних правил України «Правила повітряних перевезень та обслуговування пасажирів $і$ багажу» щодо визначення розумної межі тривалості затримки або скасування рейсу.

Розглядаючи судову практику у справах про відикодування шкоди, завданої неналежним наданням туристичних послуг у зв'язку зі скасуванням або затримкою авіарейсу, автором акиентується увага на неоднаковому вирішенні судами питання щодо суб'єкта відповідальності у иих категоріях справ. Зокрема, в одних випадках за рішенням суду компенсачія за неналежне надання туристичних послуг через скасування або затримку рейсу стягується з авіаперевізника, а в інших - з туроператора. Крім того, незважаючи на доведення факту завдання матеріальної шкоди через скасування або затримку рейсу за договором на туристичне обслуговування, суди в окремих випадках відмовляють туристам у задоволенні позовних вимог у частині стягнення моральної шкоди.

Акиентується увага на необхідності тлумачення авіаперевезення як невід'ємної складової частини туристичного продукту за договором на туристичне обслуговування. Визначено дочільність введення презумпиії відповідальності туроператора за неналежне надання туристичних послуг, зокрема у разі скасування або затримки рейсу, шо відповідає положенням європейського законодавства про відшкодування шкоди за договорами на туристичне обслуговування та практиці Суду справедливості Європейського Союзу.

Ключові слова: договір на туристичне обслуговування, відшкодування шкоди, затримка рейсу, скасування рейсу, туристичні послуги, права туриста.

Постановка проблеми. Протягом останніх років спостерігається систематичне зростання кількості українців, які відпочивають за кордоном. Так, приріст виїзного потоку туристів-громадян України за перше півріччя 2019 року зріс на 5,6\% порівняно з аналогічними періодами за минулі роки та становить 13627 осіб [1]. Однак не всі туристичні подорожі супроводжуються наданням на належному рівні туристичних послуг, зокрема у сфері авіаперевезення. Під час туристичного сезону в Україні постійно з'являються повідомлення про вітчизняних туристів, які не можуть вилетіти додому 3 відпочинку.
Наприклад, влітку 2018 року більше тисячі українців застрягли в аеропортах Грузії, Туреччини, Албанії та Єгипту, оскільки туроператор Join Up не оплатив послуги авіаперевізника Bravo Airways [2].

За статистичними даними Європейського Союзу, щороку лише двом відсоткам туристів вдається довести у суді своє право на компенсацію за скасування або перенесення рейсу [3]. В Україні аналогічна статистика не ведеться, однак у Реєстрі судових рішень є справи щодо відшкодування шкоди, завданої неналежним наданням туристичних послуг у зв'язку із скасуванням або затримкою авіарейсу. 
Про важливість якісного авіасполучення як складової частини договорів на туристичне обслуговування свідчать також положення Пам'ятки для туристів Міністерства розвитку економіки, торгівлі та сільського господарства України 2019 року, у яких українським туристам рекомендують перевіряти місце авіакомпанії у Рейтингу пунктуальності виконання рейсів Державіаслужби України [4].

Збільшення кількості українців, що відпочивають за кордоном, наявність систематичних повідомлень про затримку рейсів 3 українськими туристами під час туристичного сезону, незначна кількість справ, за якими туристам вдається стягнути компенсацію за неналежне авіасполучення під час туристичної подорожі, свідчать про актуальність дослідження сучасного стану та перспектив розвитку законодавства України у сфері відшкодування шкоди за скасування або затримку авіарейсу за договором на туристичне обслуговування.

Аналіз останніх досліджень і публікацій. Вагомий внесок у вивчення поняття, правової природи, особливостей укладення, виконання та припинення цивільно-правових зобов'язань у сфері туризму здійснили Б.І.Вихристенко, М.М.Гудима, Н.М.Зільник, В.О. Кохановський, В.В. Луць, О.Ю. Серьогін, Н.I. Турчак, Н.В. Федорченко, Р.I. Яворський. Проблематиці виконання договорів на туристичне обслуговування та відшкодування шкоди за порушення надання туристичних послуг присвячені публікації I.I. Банасевич, А.Б. Гриняка, М.М. ГудимиПідвербецької, Н.С. Камінської, М.Д. Пленюк, М.В. Семенової. Незважаючи на значну кількість наукових досліджень у сфері правового регулювання договору на туристичне обслуговування, порядок стягнення компенсації за скасування або затримку рейсу під час туристичної подорожі залишається не досить вивченим.

Мета статті - дослідження відшкодування шкоди, завданої скасуванням або затримкою авіарейсу за договором на туристичне обслуговування, виявлення проблемних аспектів отримання туристом компенсації, а також формулювання пропозицій удосконалення норм українського законодавства у цій сфері.

Виклад основного матеріалу. Для характеристики стягнення компенсації за скасування або затримку авіарейсу за договором про надання туристичних послуг першочергове значення має здійснення відмежування понять «скасування рейсу» та «затримка рейсу» 3 урахуванням норм національ- ного та європейського права, а також судової практики.

Так, зі змісту статей 5 та 6 Регламенту (СC) Європейського Парламенту та Ради від 11 лютого 2004 року № 261/2004 про запровадження загальних правил компенсації та допомоги пасажирам у разі відмови у перевезенні та скасування чи тривалої затримки рейсів (надалі - Регламент № 261/2004) випливає, що у відмежуванні затримки та скасування рейсів враховується час запланованої відправки рейсу та дальність польоту. Зокрема, затримкою для авіарейсів з дальністю польоту включно до 1500 кілометрів вважається відсутність відправки протягом 2 годин, для авіарейсів у межах $\mathrm{CC}$ та рейсів 3 дальністю польоту від 1500 до 3500 кілометрів - протягом 3 годин, а для рейсів з більшою дистанцією - відсутність відправки протягом 4 годин [5]. Для характеристики скасування рейсу стаття 5 Регламенту 261/2004 містить вказівку на обов'язок авіаперевізника надати інформацію пасажирам про альтернативні маршрути, сприяти їм у поверненні вартості квитка або пересадці на інший маршрут, однак не визначає особливостей щодо дистанції польоту чи інших характеристик у разі призначення компенсації.

Водночас відповідно до Авіаційних правил України «Правила повітряних перевезень та обслуговування пасажирів і багажу» (надалі - Авіаційні правила України) у разі визначення затримки та скасування рейсу використовується термін «розумні строки», які за пунктом 6 розділу I Авіаційних правил охоплюють дві години або більше щодо всіх рейсів дальністю 1500 кілометрів або менше, три години або більше - для всіх рейсів дальністю понад 1500 до 3500 кілометрів; чотири години або більше - для всіх інших рейсів [6].

Під час порівняння положень Регламенту ЄC № 261/2004 та Авіаційних правил України щодо співвідношення понять «затримка рейсу» та «скасування рейсу» слід звернути увагу на використання у національному законодавстві формулювань «дві години або більше», «три години або більше», «чотири години або більше». Якщо за Регламентом ЄC № 261/2004 у визначенні затримки рейсу строки є абсолютно визначеними та становлять, наприклад, у разі дальності польоту до 1500 кілометрів дві години від запланованого часу вильоту, то в Авіаційних правилах України введення терміна «розумні строки» у пункті 6 Розділу I призводять до нечіткого визначення критеріїв розмежування строків затримки рейсу. Зокрема, у разі дальності польоту до 1500 кілометрів встановлено відносний строк у дві години або більше. При цьому не визначеною залишається верхня 
межа затримки рейсу, що має ключове значення під час призначення компенсації, адже, наприклад, не можна ототожнювати збитки пасажира у разі затримки рейсу дальністю польоту до 1500 кілометрів на дві години та на 15 годин.

Офіційне тлумачення співвідношення термінів «затримка рейсу» та «скасування рейсу» під час відшкодування шкоди пасажиру встановлено у рішеннях Європейського суду (Четверта Палата) у справах № С-402/07 Крістофер Стерджен та інші проти авіакомпанії "Condor Flugdienst GmbH” та № C-432/07 Стефан Бек, Корнелія Лепушиц проти авіакомпанії "Air France SA". Відповідно до цих судових актів статті 5, 6 та 7 Регламенту № 261/2004 для вирішення питання про виплату компенсації слід застосовувати так: пасажири, рейси яких затримуються, прирівнюються до пасажирів, рейси яких скасовані, якщо затримка дорівнює або перевищує три години, тобто пасажири досягають свого кінцевого пункту призначення на три або більше годин пізніше, ніж це визначено у розкладі рейсів авіаперевізника [7].

Таким чином, затримка рейсу на три або більше годин за рішеннями Свропейського суду у справах № C-402/07 та № C-432/07 прирівнюється за цивільно-правовими наслідками до скасування рейсу та надає право туристу на аналогічну компенсацію у розмірі: 250 євро за авіарейсами із дальністю польоту до 1500 км; 400 євро за авіарейсами із дальністю польоту від 1500 до 3500 км; 600 євро - для всіх інших авіарейсів. Якщо затримка рейсу становить менше як три години, то, застосовуючи тлумачення із наведених вище судових рішень Європейського суду та положення пункту а) параграфу 1 статті 8 Регламенту № 261/2004, пасажир має право на забезпечення прохолодними напоями та харчуванням під час очікування відправки рейсу, на поселення в готелі, якщо час очікування у разі зміни маршруту становить одну або кілька ночей або на відшкодування повної вартості квитка на авіарейс.

Отже, визначення у рішеннях Європейського суду у справах № С-402/07 та № C-432/07 мінімального строку у три години для встановлення компенсації за затримку рейсу у тому ж самому розмірі як у разі скасування авіаперельоту розширює права туристів на отримання відповідного відшкодування. На відміну від європейського законодавства, згідно з главою 4 розділу XV Авіаційних правил України пасажири, рейс яких затримують, мають право від авіаперевізника на забезпечення напоями, харчуванням, здійснення двох безкоштовних дзвінків чи повідомлень, а у разі затримки рейсу на більше як 5 годин - відшкодування вартості повітряного перевезення або зміну маршруту. Таким чином, право на отримання грошової компенсації за затримку рейсу за Авіаційними правилами України максимально визначене у розмірі вартості квитка та буде однаковим у разі затримки рейсу на 5 годин чи на 15 годин.

3 метою гармонізації українського законодавства із нормами Регламенту СС № 261/2004 та судовою практикою Свропейського суду у справах про стягнення компенсації за скасування або затримку рейсу слід уточнити положення Авіаційних правил України щодо строків затримки авіарейсу, зокрема із визначення тривалості «розумних строків» потрібно видалити формулювання «або більше» та викласти пункт 6 розділу I Авіаційних правил України «Правила повітряних перевезень та обслуговування пасажирів і багажу» у такій редакції: «розумні строки - період часу, розумна межа тривалості якого під час повітряного перевезення пасажира (багажу) становить дві години щодо всіх рейсів дальністю 1500 кілометрів або менше; три години - для всіх рейсів дальністю понад 1500 до 3500 кілометрів; чотири години - для всіх інших рейсів». У точнення тривалості строків сприятиме більш чіткому відмежуванню розумних строків затримки рейсів із різною дальністю польоту.

Крім цього, 3 метою забезпечення прав туристів та інших пасажирів на відшкодування шкоди слід передбачити можливість отримання компенсації за затримку авіарейсу у розмірі вищому, ніж вартість квитка та викласти пункт 3 глави 4 розділу XV Авіаційних правил України у такій редакції: «У разі затримки рейсу понад розумні строки авіаперевізник має забезпечити пасажирам можливість зміни маршруту або відшкодувати вартість авіаперевезення, а у разі затримки рейсу понад 3 години пасажири мають право на отримання компенсації у розмірі, визначеному пунктом 5 глави 2 розділу XV Авіаційних правил України», тобто за аналогією із судовою практикою Європейського суду передбачити у законодавстві право пасажира отримати відшкодування за затримку рейсу понад три години у розмірі, аналогічному, як у разі скасування рейсу.

Під час розгляду справ щодо стягнення компенсації, завданої туристу затримкою або скасуванням авіарейсу, використовується загальноприйнятий у цивілістиці підхід до умов настання цивільно-правової відповідальності, що охоплює: наявність шкоди, протиправність поведінки особи, що заподіяла шкоду, причинний зв'язок між цією поведінкою та завданою шкодою, а також 
вина заподіювача шкоди. Відповідно до статей 22 та 23 Цивільного кодексу України шкода поділяється на майнову (реальні збитки та упущена вигода) та моральну.

У разі скасування або затримки авіарейсу наявна як майнова, так і моральна шкода. Однак суди, задовольняючи позовні вимоги щодо стягнення майнової шкоди, в окремих випадках відмовляють у стягненні моральної шкоди за порушення договорів на туристичне обслуговування. Наприклад, у рішенні у справі № 761/6433/18 Шевченківський районний суд м. Києва зобов'язав туроператора оплатити майнові збитки за ненадані туристичні послуги в сумі 36 899,00 грн, однак відмовив у стягненні моральної шкоди, оскільки позивач не надав доказів, які підтверджували б іï настання [8]. У зв’язку з цим слід закцентувати увагу на правовій позиції Верховного Суду у справі № 761/35935/15-ц від 30 жовтня 2019 року, у якій встановлено, що під час вирішення питання про стягнення моральної шкоди за неналежне надання туристичних послуг суди мають враховувати, що за ч. 1 ст. 25 Закону України «Про туризм» туристи мають право на відшкодування моральних збитків. Оскільки рейс позивачів було затримано, а туроператор не надав послуги трансферу із аеропорту до готелю, це призвело до душевних хвилювань туристів і розчарування від подорожі. Також туроператор не надав доказів того, що моральна шкода була компенсована ним добровільно або шляхом надання додаткових туристичних послуг, тому суд задовольнив частково касаційну скаргу та зобов'язав туроператора виплатити туристам моральну шкоду [9]. Отже, під час розгляду справ про стягнення шкоди за скасування або затримку авіарейсу за договором на туристичне обслуговування у разі наявності достатніх підстав для стягнення майнової шкоди моральна шкода також підлягає компенсації.

Також необхідною умовою настання цивільно-правової відповідальності за завдання шкоди $€$ протиправність поведінки заподіювача шкоди. Окрему увагу слід звернути на те, що суди неоднаково вирішують питання про суб'єкта відповідальності у справах про стягнення компенсації за скасування чи затримку авіарейсу за договором про надання туристичних послуг. В одних випадках цим суб'єктом є туроператор, адже він відповідає за організацію туристичної подорожі, а в інших судових справах - авіакомпанія, яка безпосередньо забезпечує авіапереліт, що підтверджується матеріалами судової практики.

Наприклад, у провадженні Івано-Франківського міського суду Івано-Франків- ської області розглядалась цивільна справа за позовом фізичної особи до турагентства ТОВ «Туристична компанія «КРАСНА» та туроператора ТОВ «Оазіс Тревел Україна» про стягнення шкоди, завданої невиконанням умов договору на туристичне обслуговування. Відповідно до матеріалів справи позивачем було сплачено турагенту «Туристична компанія «КРАСНА» грошові кошти за туристичну подорож до Тунісу, однак через скасування авіарейсу туристичні послуги не були надані. У рішенні суду від 05.06.2019 р. до майнової відповідальності за порушення договору на туристичне обслуговування було притягнуто туроператора [10].

Натомість в аналогічному випадку у рішенні Корольовського районного суду м. Житомира від 18.10.2019 р. збитки за скасування авіарейсу було стягнуто з авіакомпанії ТОВ «ЯНЕІР» ЛТД у розмірі фактично сплачених коштів за договором про надання туристичних послуг загальною сумою 18 340,74 гривень [11].

Також поширеною є ситуація, коли за ненадання туристичних послуг через скасування авіарейсу притягують солідарно туроператора та авіакомпанію, зокрема туроператор відшкодовує кошти, сплачені туристом за туристичну подорож, а авіакомпанія сплачує компенсацію за скасування авіарейсу. Наприклад, рішенням Ленінського районного суду м. Харкова від 21.03.2019 р. за порушення договору на туристичне обслуговування до цивільно-правової відповідальності було притягнуто солідарно туроператора та авіперевізника, а саме із туроператора ТОВ «Оазіс Тревел Україна» стягнуто збитки у розмірі сплачених позивачем коштів за договором на туристичне обслуговування та пеню, а з авіаперевізника ТОВ «Авіакомпанія Браво» - компенсацію за скасування авіарейсу до Тунісу [12].

Враховуючи наведені приклади судової практики, для відмежування відповідальності туроператора та авіаперевізника за скасування авіарейсу слід враховувати, що визначення суб'єкта, протиправність поведінки якого призвела до неналежного надання туристичних послуг, залежить в основному від змісту договору на туристичне обслуговування. На практиці у ці договори часто включають положення про те, що туроператор не несе відповідальності за скасування авіарейсу або передає відповідні претензії на розгляд авіакомпанії. Наприклад, у Типовому договорі на туристичне обслуговування туроператора «Зевс Тревел» у пункті 8.4. щодо відповідальності сторін вказано, що у випадках скасування чи зміни часу відправлення та/чи прибуття регулярних рей- 
сів туроператор передає претензії туриста на розгляд авіакомпанії [13]. Включаючи відповідні положення до тексту договору, туроператор страхує себе від відповідальності.

Однак відповідно до статті 20 Закону України «Про туризм» за договором на туристичне обслуговування туроператор зобов'язується надати туристу комплекс туристичних послуг (туристичний продукт), а згідно з положеннями статті 1 цього Закону, туристичний продукт поєднує не менше ніж дві такі послуги, зокрема послуги перевезення, послуги розміщення та інші туристичні послуги [14]. Таким чином, законодавець визначає послуги перевезення як невід'ємну складову частину договору на туристичне обслуговування і туроператор, реалізуючи туристичний продукт, відповідає за його виконання у повному обсязі.

Оскільки авіаперевезення входить до складу туристичного продукту, то і відповідальність за скасування або затримку рейсу має нести перед туристом не авіаперевізник, а туроператор. Це відповідає також європейській судовій практиці. Зокрема, відповідно до рішення Суду справедливості Європейського Союзу від 10 липня 2019 року у справі № C 163/18 пасажири, які постраждали від скасування рейсу, що є частиною пакетної туристичної подорожі, не можуть вимагати від авіаперевізника відшкодування, а мають право на компенсацію вартості квитків у організатора своєї поїздки [15]. При цьому право на компенсацію від організатора поїздки зберігається також у разі, якщо він фінансово не здатний відшкодувати вартість квитка і не вживає заходів для гарантії такого відшкодування.

\section{Висновки}

3 метою уніфікації правового механізму притягнення до відповідальності за шкоду, завдану скасуванням або затримкою авіарейсу за договором на туристичне обслуговування, статтю 20 Закону України «Про туризм» варто доповнити презумпцією відповідальності туроператора за неналежне авіаперевезення. Введення цієї презумпції відповідає концепції єдності і неподільності туристичного продукту, судовій практиці Європейського Суду справедливості та спрямоване на покращення захисту прав туристів у цій сфері, а практично забезпечуватиметься у межах статті 15 Закону «Про туризм», згідно з якою туроператор має обов'язково здійснити фінансове забезпечення своєї цивільної відповідальності.

\section{Список використаних джерел:}

1. Департамент туризму та курортів. Інформація щодо відвідування України іноземними туристами та виїзду громадян України за кордон. I півріччя 2016-2019 років. URL: http://www.me.gov.ua/Documents/List?lang=ukUA\&id=be44a1a7-69b3-4a77-a86a-447499abcdd6 \&tag=Analitika\&isSpecial=true (дата звернення: 04.02.2020)

2. Без воды, еды и объяснений. Как украинцы стали «заложниками» заграничных аэропортов и кто за это ответит. URL: https://112.ua/glavnyenovosti/bez-vody-edy-i-obyasneniy-kak-ukraincystali-zalozhnikami-zagranichnyh-aeroportov-ikto-za-eto-otvetit-452274.html (дата звернення: 04.02.2020)

3. Busson Th. Delayed Flight Compensation: A Complete Guide to Know How to Claim. URL https://www.claimcompass.eu/blog/delayed-flightcompensation/ (дата звернення: 04.02.2020).

4. Пам'ятка для туристів Міністерства розвитку економіки, торгівлі та сільського господарства України від 04.06 .2019 р. URL: http://www.me.gov.ua/Documents/Detail?lang= uk-UA\&id=42e3bc7a-2dec-42b2-9e3b-4cbdc 4364 $84 \mathrm{e} \&$ title $=$ PamiatkaDliaTuristiv \&isSpecial $=$ true (дата звернення: 04.02.2020).

5. Регламент (ЄС) Європейського Парламенту та Ради про запровадження загальних правил компенсації та допомоги пасажирам у разі відмови у перевезенні та скасування чи тривалої затримки рейсів від 11 лютого 2004 року № 261/2004. URL: https://zakon.rada.gov.ua/laws/ show/994 912 (дата звернення: 04.02.2020).

6. Про затвердження Авіаційних правил України «Правила повітряних перевезень та обслуговування пасажирів і багажу» : Наказ Державної авіаційної служби України від 26.11.2018 №1239.URL:https://zakon.rada.gov.ua/laws/show/ z0141-19\#top (дата звернення: 04.02.2020).

7. Joined Cases of European Court No. C-402/07 and No. C-432/07 from November, 19, 2009. URL: https://eur-lex.europa.eu/legal-content/ $\mathrm{EN} / \mathrm{TXT} /$ ?uri=CELEX\%3A62007CJ0402 （дата звернення: 04.02.2020)

8. Рішення Шевченківського районного суду м. Києва від 13 вересня 2018 р., судова справа № 761/6433/18. URL: http://www.reyestr. court.gov.ua/Review/77036511 (дата звернення: 04.02.2020).

9. Правовапозиція Верховного Суду від 30 жовтня 2019 р., судова справа № 761/35935/15-ц. URL: https://zakononline.com.ua/court-decisions/ show/85582027 (дата звернення: 04.02.2020).

10. Рішення Івано-Франківського міського суду Івано-Франківської області від 05 червня 2019 р., судова справа № 344/17019/18. URL: http://www.reyestr.court.gov.ua/Review/ 82415446 (дата звернення: 04.02.2020). 
11. Рішення Корольовського районного суду м. Житомира від 18.10.2019 р., судова справа № 296/359/19. URL: http://www.reyestr.court.gov.ua/Review/ 86253715 (дата звернення: 04.02.2020).

12. Рішення Ленінського районного суду м. Харкова від 21.03.2019 р., судова справа № 642/6923/18. URL: https://youcontrol.com.ua/ catalog/court-document/80771596/ (дата звернення: 04.02.2020).

13. Типовий договір на туристичне обслуговування туроператора «Зевс Tревел». URL http://www.zeus.travel/texts/docum/ tourist_treatment.pdf (дата звернення: 04.02.2020)

14. Про туризм : Закон України від 15.09.1995 № 324/95-ВР зі змінами та доповненнями. Відомості Верховної Ради України. 1995. № 31. Ст. 24 .

15. Рішення Суду справедливості Європейського Союзу від 10 липня 2019 р., судова справа № C 163/18. URL: http://curia.europa.eu/juris/ document $/$ document.jsf?text $=\&$ docid $=216037 \&$ pageIndex $=0 \&$ doclang $=E N \&$ mode $=$ req $\&$ dir $=\&$ occ=first\&part=1\&cid=3615049 (дата звернення: 04.02.2020).

The article is concerned with analysis of recovery of damages problematic for cancellation or flight delay to the extent that aviation operations is a part of tourism product under Agreement for tourist services. On the ground of the analysis of the norms of the Ukrainian legislation, the Law of the European Union and the Jurisprudence in cases of compensation of damage inflicted by inappropriate provision of tourist services, realization of concept delimitation of "flight cancellation" and "flight delay". The author grounded that the use of the term "reasonable timeframes" in the Ukrainian legislation in characterizing the flight delay and flight cancellation causes a fuzzy definition of the criteria for their delimitation when deciding the assignment of compensation. On the ground of the characteristics of the European Court, it is proposed to clarify paragraph 6 of section I of the Aviation Rules of Ukraine "Rules for the Air Conveyance and Passenger and Passenger and Baggage Handling" conceivably reasonable limit of delay or cancellation of flight.

In consideration of the case law on compensation of damage inflicted by the inappropriate provision of tourist services, on grounds of cancellation or delay of flight, the author focuses his attention on the unequal court decision regarding the subject of liability in these categories of cases. In particular, in some cases, compensation for improper provision of tourist services through cancellation or delay of a flight is charged to the carrier by the court and in others by the tour operator. In addition, despite proving the fact of pecuniary damage caused by cancellation or delay of flight under Agreement for tourist services, the courts in some cases refuse tourists to satisfy the claim for non-pecuniary damage.

Author focuses his attention on the need to interpret air travel as an integral part of a tourism product under Agreement for tourist services. The expediency of introducing the presumption of liability of the tour operator for the improper provision of tourist services, in particular in the event of cancellation or delay of flight, which complies with the provisions of the European legislation on compensation for damage under Agreement for tourist services and the practice of the Court of Justice of the European Union has been determined.

Key words: agreement for tourist services, compensation of damage, flight delay, cancellation of flight, tourist services, tourist rights. 